\title{
大規模施設の緑被面積と接道緑被長さの施設用途別特性について A STUDY ON THE CHARACTERISTICS OF GREEN COVERAGE AREA AND LENGTH OF ROADSIDE GREEN BY EACH TYPE OF BUSINESS AT LARGE SCALE FACILITIES IN THE CITY
}

\author{
岩尾 襄*，萩島 哲**，文 泰 憲*** \\ Noboru IWAO, Satoshi HAGISHIMA and Tae Heon MOON
}

\begin{abstract}
For the planning of urban greening it's useful to clarify the relationship between the green coverage areas and the total site area at large scale facilities in the city, and also between the length of roadside green and the length of roadside of various facilities.

$0 \mathrm{n}$ the study of urban greening we inquired into site area, green coverage area, length of roadside green with many other factors related to the greening of facilities, at 546 sites in Kumamoto city.

With this data, the ratio of green coverage and the ratio of green length at roadside, compared with each type and size of the large scale facilities, are analyzed and interpreted.
\end{abstract}

Keywords: green coverage area, length of roadside green, ratio of green coverage,

large scale facilities

緑被面積 接道緑被長さ緑被率 大規模施設

1 はじめに

1.1 研究の背景と目的

都市内の各種施設の敷地内に於ける緑化は、地区レベ ルでの緑化推進に重要な意義を有している。このため、 多くの自治体でこれ等施設に対する緑化基準注1)を設け 推進に努めているが、施設の多くが民有地であり、都市 化の進展と共に敷地の狭小化、高密度化が進んでいるた め、施設内緑化の推進は大きな課題となっている。

都市内の施設緑化に関しては、大規模な施設に較べて 小規模な施設の緑化は制約条件がきびしく、緑化の推進 は困難と考えられる。又、地区レベルでのまとまった緑 を保全、整備するためには、一定の大規模な施設に於け る緑化の推進が必要となる。

加えて、緑化のみならず、これ等施設内の既存緑地も 長期にわたって維持・保全することはかなりの努力が必 要とされ、急速に失われていく可能性がある。施設内の 緑地の重要性については、都市緑化推進計画でも指摘さ れている 注2) が、各施設の緑地に関する統計は少なく、
その実態は充分把握されてはいない。

このため本研究では、敷地面積が $500 \mathrm{~m}^{2}$ 以上 $50,000 \mathrm{~m}^{2}$ 未満の施設（以下大規模施設と名付ける）に限定して、 (1)大規模施設内では、現状でどれ程の緑被面積（本研究 では樹木の緑で被われた敷地内の面皘を緑被面積と規定 している）及び接道緑被長さ（同じく樹木の緑で被われ た敷地の接道部分の長さを規定している）を有している か、その特徴及び都市緑化に於ける重要性を確認し、(2)そ の大規模施設内では、緑化可能な面積及び緑化可能な接 道部分の長さがどれ程得られるか、さらに、(3)この大規 模施設の管理者は、これらの緑化についてどのように考 えているかを明らかにすることを目的としている。

ところで大規模施設は、市街地におよそどれ程あるの

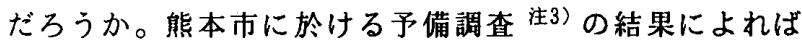
校区面積に対する大規模施設面積の割合は、最大の校区 で $43.1 \%$ 、全調查区の平均では $21.2 \%$ となっている。 5 ha 以上の施設を加えると、50\%を超える地区も見られ、 地域面積に占める割合はかなり高い。従ってこれらの大
$*$ 九州東海大学工学部建築学科 助教授・工修

** 九州大学工学部建築学科 教授 . 工博

**** 九州大学工学部建築学科大学院 大学院生・工修
Assoc. Prof., Dept. of Architecture, Faculty of Engineering, Kyushu-Tokai Univ., M. Eng.

Prof., Dept. of Architecture, Faculty of Engineering, Kyushu Univ., Dr. Eng.

Graduate student, Dept. of Architecture, Faculty of Engineering, Kyushu Univ., M. Eng. 
規模施設に於ける緑化は、都市緑化に重要な位置を占め ることが分る。

これまで、都市内の施設とその緑被面積等に関する研 究には、居住環境地区に於ける緑被空間についてその共 用化を論したたの や、住宅地の接道部の緑化について 述へたもの 2 、住宅地の敷地規模と緑被構造について述 べたもの 324)等多数がみられる。このほか、住宅市街地 に於ける土地利用用途別の緑被率について述へたもの5 や、住宅敷地及び特定施設についての都市緑化基準(案) 策定調查 注4) 等に於いても、施設と緑被空間について記 されている。このように、これまでは住宅教地に関する 報告が多く、非住宅敷地を含めて、その施設用途別特性 を述べたものは少ない。本研究では、各施設用途の特性 を統計的性質によって把握している。

\section{2 調查の概要}

大規模施設内の土地利用は、予備調查に於ける検討結 果に基づいて、最終的に下記 10 種にまとめて本研究の対 象とした。

「幼・保育園」：幼稚園、保育園

「学校」：小中学校、高校、大学、専門学校

「病院」: 病院、医院、福祉施設

「文化・体育」：文化施設、屋内体育施設

「社寺」：社寺、教会、墓地

「公園・運動場」：公園、運動場、ゴルフ練習場

「戸建住宅」：1 戸建住宅

「住宅団地」：アパート、集合住宅団地

「スーパー」：スーパー、ドライブイン、展示場

「工場・倉庫」：工場、倉庫、資材置き場、工務店

調查の概要は以下の通りである。

対象地区は、熊本市の市街化区域内にあって、用途地 域及び都心からの距離に偏りがないような21小学校区を 選んだ（図-1）。総面積3.033ha（市街化区域面積の33 $\%$ ）、地区人口 199,488 人（S60年、市人口の $36 \%$ ）であ る。1 小学校区の平均では、面積が 144 ha、人口が9488人 となっている。

対象施設は、この小学校区内に存在する大規模施設で 農地、樹林地、空地、及び建築予定地を除いて、敷地面 皘約 $0.05 \mathrm{ha} \sim 5 \mathrm{ha}$ の独立した施設である。予備調查の資 料をもとに、施設用途別、用途地域別のサンプル数に極 端な偏りが無いように配㦄して、546施設を抽出した。但 し、幼・保育園、学校等で運動場の面積等を規定した施 設設置基準 注5) を充たしていない施設は除外している。 又、幼稚園と社寺、有料駐車場と社寺など、同一敷地内 の複合的な施設は除外している。

次に、大規模施設敷地内の調查にあたって、施設内土 地利用を図-2のように区分した。敷地構成は、建築用地 と非建ぺい地から成り、非建ぺい地は、交通用地（通路、 駐車場等）、作業用地（資材置場、屋外展示場、作業場等）

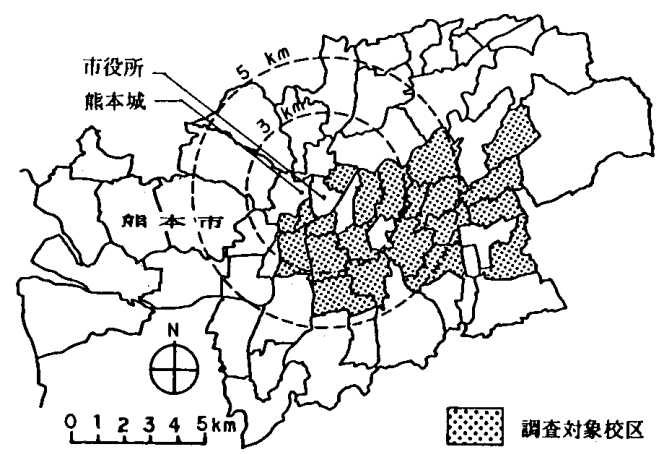

図-1 調查校区位置図

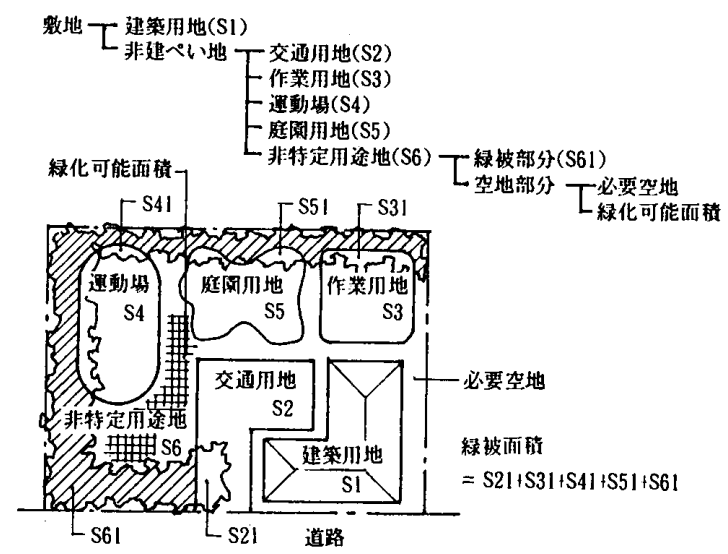

図-2 施設内土地利用区分

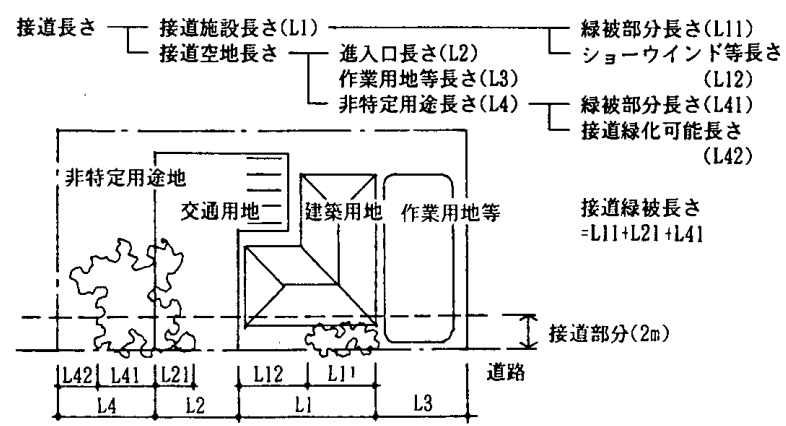

図-3 接道部分利用区分

運動場（運動場、遊び場等）、庭園用地（芝生、低木植栽、 池水、烟等) 等の特定用途地亡、非特定用途地（上記土地 利用に含まれない土地）に区分する。そして敷地面積と 共に各用地の面積を計測した。

さらに緑被面積を計測した。これは非建ぺい地が緑で 被われている部分の面積で、例えば交通用地の一部、作 業用地の一部、運動場の一部、庭園用地の一部、及び非 特定用途地の緑被部分等、敷地が緑で被われている部分 の面積の合計である。敷地よりはみ出した部分は除外し て計測した。なお、緑被面積は樹木緑被面皘に限定して いる。これは都市的生活圈における緑の中核は樹林や樹 木であるとする意見 ${ }^{6)}$ と、近年、自治体での統計が㰾木 緑被を緑被面積としている例 注6) が增えていること等に よる。庭園用地内の樹木緑被部分は緑被面積とした。 
次に、接道部分（既往の研究 ${ }^{7)}$ に従い道路境界より $2 m$ 以内の部分と規定した）についても、図-3のように区分 した。接道長さは、接道施設長さ（接道部分の建築等壁 面長さ）と接道空地長さから成り、接道空地長さは、更 に進人口長さ、作業用地等長さ（交通用地、作業用地、運 動場、庭園用地等長さ）の特定用途長さ之、非特定用途長 さに区分した。そして、接道長さと共にこれらの項目に ついて計測した。又、接道部分の全ての緑被長さを、接 道緑被長さとして計测した。

調查資料は、熊本市都市基本図 $S=1 / 2500$ 、住宅地図、力 ラ一航空写真 (平成元年 6 月初旬から中旬に撮影、縮尺 1/2500）注7）を使用した。調查方法は、航空写真及び、 住宅地図による敷地確認などを行った後、縮尺 $1 / 500 に$ 拡大した地図に航空写真から緑被部分を写しとり、現地 調查で確認の後、デジタイザーで計測した。敷地利用状 況についても同様に調查し、現地での用途区分等の照合 を行いその妥当性を確認した。

測定に際しての航空写真による判定は、細部を拡大鏡 を用いることにより、写真上の $0.5 \mathrm{~mm}$ (実寸 $1.25 \mathrm{~m}$ ）まで 判別可能であり、計測の精度はかなり高い。（縮尺 $1 / 500$ に搪大した地図のデシタイザーによる計測誤差は2.10\% であった〉しかし、判別の困難な幅 $1 \mathrm{~m}$ 未満の低木や生け 垣等は緑被面積、接道緑被長さの対象から除外して、樹 木（高木）の樹冠投影面積を緑被面積として計測した。

ところで、大規模施設の施設内緑化には、緑被面積で 捉えられる緑の量のほか、主として敷地外からの景観上 求められる、道路に面する表の緑としての接道緑被長さ の抁大がある。そこで、本研究では施設内土地利用と接 道部分の用途の二つの観点から緑被などの調查を行って いる。

2 紓被面積及び接道緑被長さについて

$2 \cdot 1$ 調查結果の概要

全546の大規模施設について、調查結果を施設当りの 平均値で表すと、表一1のごとく示される。

(1)線被面積

施設用途別に緑被面積の平均値をみると、学校、社寺、 公園・運動場で $1000 \mathrm{~m}^{2}$ を超えており、これらの施設で相 当量の緑が存在していることを示している。緑被面積が 少ないものでは、スーパー、工場・倉庫がある。このよ うに、大規模施設の緑被面積は、施設用途によりかなり の莣が見られる。

緑被面積の敷地面積に対する割合（緑被率）では、社 寺や戸建住宅、公園・運動場が高く、緑化貢献度の高い 施設となっている。反対に、緑化に対する貢献度の低い 施泮として、スーパー、工場・倉庫等があり、これらは地 区レベルでの緑被率を低下させる要素となっている。
表-1 緑被面皘等の施設用途別平均値

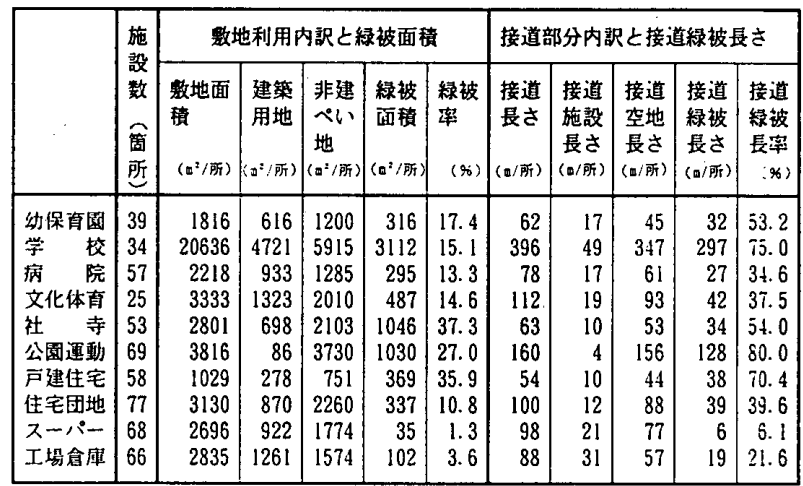

\section{(2)接道緑被長さ}

接道緑被長さでは、学校が $297 \mathrm{~m} /$ 所で最大となり、次 いで公園・運動場で、学校と共に街路景観に大きく貢献 していることが認められた。

また、接道長さに対する接道緑被長さの割合（接道緑 被長さ率）では、公園・運動場や学校が高く、次いで戸 建住宅となり、これらの施設で接道部分の緑化の割合が 高いのに較へてて、スーパーでは接道部分のほとんどが緑 化されていないことが分る。

(3)まとめ

スーパー、工場・倉庫の民間系施設では、緑被面積、接 道緑被長さ共に値が小さく、ほとんど緑化されず、緑化 の度合が低いことが分った。しかし、社寺、戸建住宅、公 園・運動場は、緑被面積は多く、接道緑被長さでは、公 園・運動場、戸建住宅、学校等でよく緑化されており、こ れらの施設での緑の維持、保全の重要性が指摘出来る。

緑被率は、社寺や戸建住宅、公園・運動場で高く、ス 一パーや工場・倉庫で低い。又、接道緑被長さ率は、公 園・運動場や学校が高い值になっている。

$2 \cdot 2$ 緑被面積と非建ぺい地面積、接道緑被長さと接道 空地長さの関係

次に、本節では緑被面積と非建ぺい地面積との相関、 接道緑被長さと接道架地長さの相関を分布図を描いて検 討した。回帰分析は定数項を除いて行った。

(1)緑被面積と非建ぺい地の相関

図一4によると、施設用途別に見て相関係数は、スーパ 一を除いて0.7以上となり、正の高い相関を示している。 つまり、施設用途別に捉えると、施設固有の条件の違い にも拘らず、非建ぺい地面積が増大すると緑被面積も増 大する関係が明らかになった。

分布図を見ると、特徵的なのは学校であり、やや分散 している。そこで、学校の位置と分布図の分布状態との 關係を調へると、都心から $3 \mathrm{~km}$ 以内では $64 \%$ （7校）の学 校が、又3〜 5kmの地域では $44 \%$ （7校）の学校が回㷌直線 の上部に分布している。即ち、都心部に近い学校が、非 建ぺい地面積に対する緑被面積の割合が高いことを示し ている。 $5 \mathrm{~km}$ 以遠では、特徴は見出せない。又、用途地域 


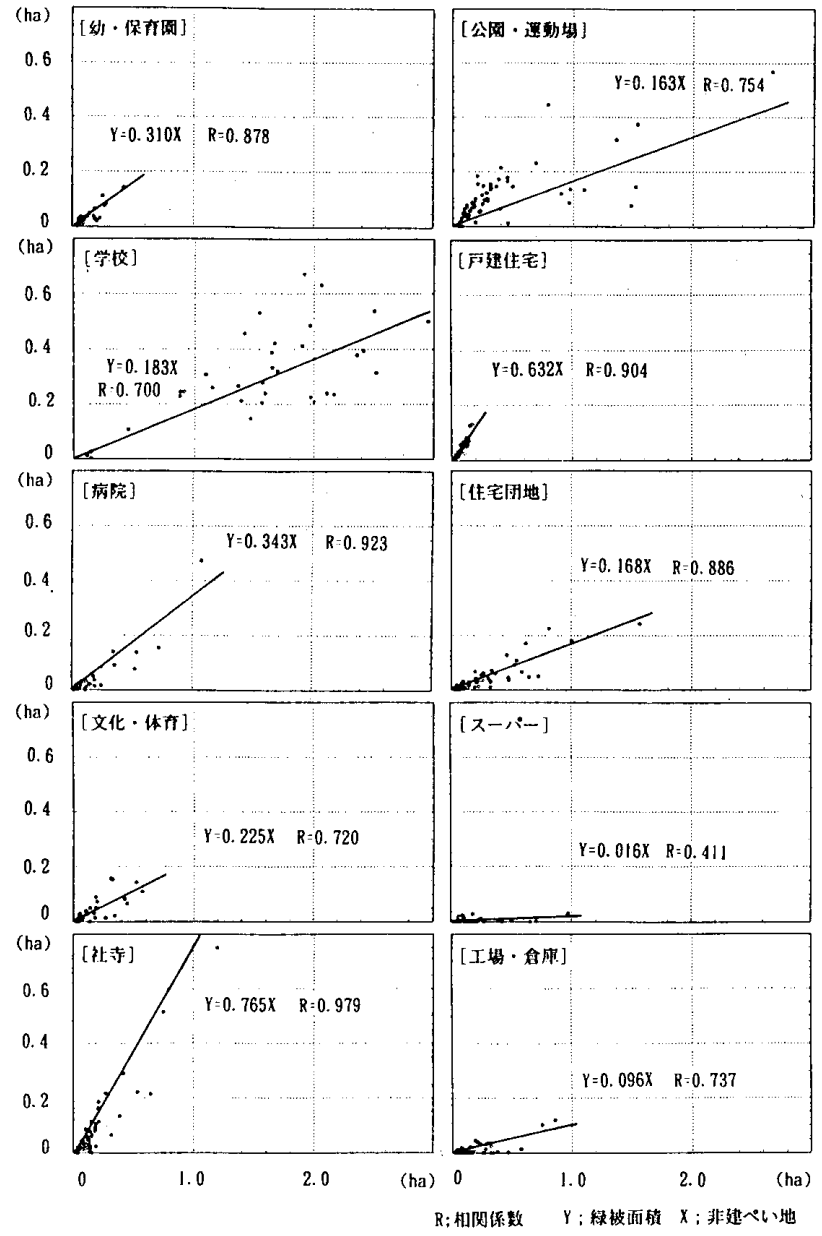

図-4 緑被面積・非建ぺい地相関図

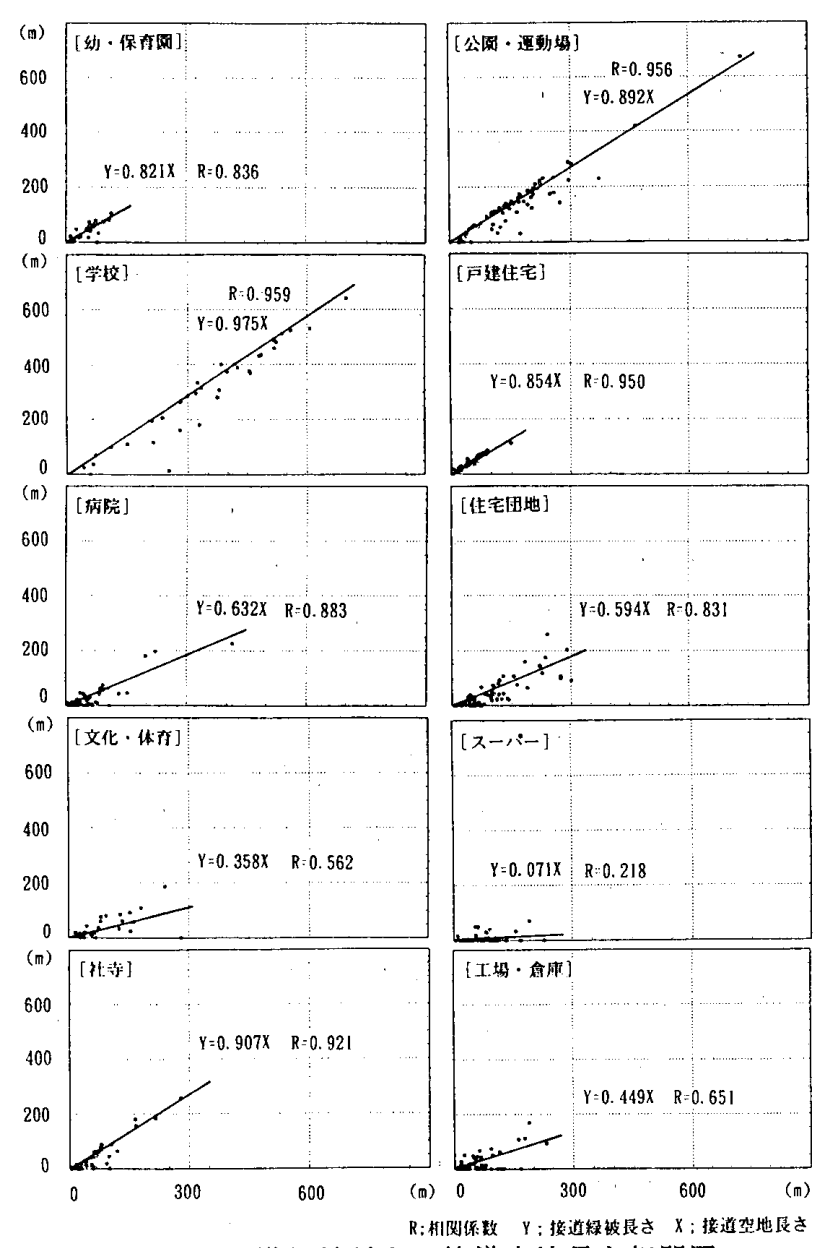

図-5 接道緑被長さ・接道空地長さ相関図

分った。

又、学校の場合は、都心部に近いほど緑被面積の割合 が高いこと、運動場は公園に較べて、緑被面積の割合が 低いことが明らかになった。

3 緑化可能面積及び接道緑化可能長さについて 次に、非建ぺい地及び接道空地長さの利用状況を調へ、 今後緑化を進めるための緑化可能な面積等について検討 してみよう。

\section{1 敷地利用及び接道部分利用の用途構成}

大規模施設の非建ぺい地及び接道空地長さに関する調 查結果をまとめ、1 箇所当たりの平均值及び構成比で示 すと、それぞれ表-2、表-3のように表はされる。

\section{(1) 政地利用亡非特定用途地}

表-2に於いて、敷地面積に対する非建ぺい地の割合は、 公国・運動場 (97.8\%) を除くと、学校の77.1\%から工 場・倉盤の $55.6 \%$ まて比較的近似した值となっている。

次に、非建ぺい地に占める各土地利用の割合は、戸建 住宅、社寺、幼 - 保有園、病院、文化・体有では非特定用途 地の割合が最も高く、公國・運動場、学校では速動場の 割合が高い。スーパーや住宅団地は交通用地が高く、工 
表-2 施設内土地利用の施設用途別平均值

\begin{tabular}{|c|c|c|c|c|c|c|c|c|}
\hline & \multicolumn{6}{|c|}{ 非建ぺい地内档（四 $/$ /所） } & \multicolumn{2}{|c|}{ 非特定地内訳 $\left(0^{2}:\right.$} \\
\hline & 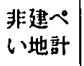 & $\begin{array}{l}\text { 公通用 } \\
\text { 地 }\end{array}$ & $\begin{array}{l}\text { 作業用 } \\
\text { 地 }\end{array}$ & 遇動埸 & $\begin{array}{l}\text { 庭園用 } \\
\text { 地地 }\end{array}$ & $\begin{array}{l}\text { 非特定 } \\
\text { 用途地 }\end{array}$ & $\begin{array}{l}\text { 粶被部 } \\
\text { 分 }\end{array}$ & $\begin{array}{l}\text { 空地部 } \\
\text { 分* }\end{array}$ \\
\hline & 1200 & 70 & 17 & 521 & 56 & 536 & 217 & \\
\hline & (66.2) & $(3.8)$ & $(0.9)$ & (28.7) & (3.1) & (29.5) & $(11.9)$ & $(17.6)$ \\
\hline & 15915 & 1506 & 613 & 7846 & 513 & 5437 & 2541 & 2896 \\
\hline & $(77.1)$ & $(7.3)$ & ( 2.9$)$ & $(38.0)$ & $(2.4)$ & (26.3) & (12.3) & $(14.0)$ \\
\hline \multirow{2}{*}{ 病院 } & 1285 & 426 & 26 & 119 & 102 & 612 & 238 & 374 \\
\hline & $(58.0)$ & $(19.2)$ & $(1.1)$ & ( 5.3$)$ & $(4.6)$ & $(27.6)$ & $(10.7)$ & (16.9) \\
\hline 文化体育 & 2010 & 858 & 33 & 56 & 174 & 889 & 400 & 489 \\
\hline \multirow{2}{*}{ 社 寺 } & $\begin{array}{r}0.4) \\
2103\end{array}$ & 251 & $\begin{array}{l}1.07 \\
307\end{array}-1-10$ & 1.6) & $5.2)$ & (26.7) & $\mid \begin{array}{l}(12.0) \\
893\end{array}$ & (14.7) \\
\hline & $(75.2)$ & $(8.9)$ & $(10.9)$ & 0.4) & ( 6.6$)$ & $(48.0)$ & $(31.8)$ & $(16.2)$ \\
\hline \multirow[t]{2}{*}{ 公園運動 } & 3730 & 129 & & 2235 & 112 & 1207 & 805 & 402 \\
\hline & (97.8) & (3.3) & $(1.2)$ & (58.5) & $(2.9)$ & $(31.6)$ & $(21.1)$ & 10.5) \\
\hline \multirow{2}{*}{ 户建住宅 } & 751 & 60 & & 0 & 163 & 519 & 311 & 208 \\
\hline & $(73.2)$ & $(5.8)$ & $(0.9)$ & & 15.8) & $(50.4)$ & $(30.2)$ & $(20.2)$ \\
\hline \multirow{3}{*}{ 住宅团地 } & 2260 & 967 & 7 & 100 & 321 & 865 & 276 & 589 \\
\hline & (72.2) & $(30.9)$ & $(0.2)$ & (3.2) & $(10.2)$ & $(27.5)$ & $(8.7)$ & $(18.8)$ \\
\hline & 1774 & 861 & 547 & 1 & 13 & 352 & & 320 \\
\hline \multirow{2}{*}{ 工場倉庫 } & 65. & 297 & $(20.2)$ & & $\begin{array}{r}(0.4) \\
\end{array}$ & $(13.0)$ & $(1.1)$ & (11.9) \\
\hline & $(55.6)$ & $(10.4)$ & (24.7) & & ( 1.4$)$ & $(18.8)$ & (3.1) & (15.7) \\
\hline
\end{tabular}

注 （）内は数地面皘に対する\%を示す。*必要空地及び緑化可能面皘

表-3 接道空地長さの施設用途別平均値

\begin{tabular}{|c|c|c|c|c|c|c|}
\hline & \multicolumn{4}{|c|}{ 接道空地長さ内訳(田) } & \multicolumn{2}{|c|}{ 非特定長さ內㰴（m） } \\
\hline & 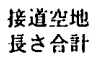 & $\begin{array}{l}\text { 進入口舆 } \\
\text { さ }\end{array}$ & $\begin{array}{l}\text { 作業用地 } \\
\text { 等長さ }\end{array}$ & $\begin{array}{l}\text { 非特定抽 } \\
\text { 途長さ }\end{array}$ & 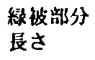 & $\begin{array}{l}\text { 接道緑化 } \\
\text { 可能辰さ }\end{array}$ \\
\hline 级保资園 & & & & & 27 & \\
\hline 毲校 & 2.6) & $(14.5)$ & (11.9) & (47.4) & {$[90.0]$} & {$[10.0]$} \\
\hline 学: 成 & 347 & 23 & 15 & 308 & 287 & 21 \\
\hline 病院 & $\begin{array}{r}61 \\
61\end{array}$ & 24 & 8 & & .61 & \\
\hline & $(79.5)$ & $(30.8)$ & $(10.2)$ & $(37.7)$ & {$[80.0]$} & {$[20.0]$} \\
\hline 文化体自 & 93 & 30 & 19 & 44 & & \\
\hline & (84. 8) & $(26.8)$ & (17.3) & $(39.8)$ & 9] & 1] \\
\hline 社 寺 & $\begin{array}{l}53 \\
3)\end{array}$ & 13 & 8 & $\begin{array}{r}32 \\
1.7\end{array}$ & $\begin{array}{r}30 \\
{[93.8]}\end{array}$ & 6.21 \\
\hline 公图遇動 & 156 & 14 & 10 & 132 & 125 & \\
\hline & $(98.1)$ & $(9.4)$ & (6.7) & $(81$ & [94. 7] & [ 5.3] \\
\hline F建住宅 & 44 & & & 36 & & \\
\hline 伐宅 & (83. 3) & 3.0) & ( 5.7$)$ & 4) & [94. 5] & [ 5.5] \\
\hline & $(88.2)$ & $(21.0)$ & $\begin{array}{r}23 \\
(23.9)\end{array}$ & $(43.7)$ & $\begin{array}{r}38 \\
{[86.4]}\end{array}$ & 6] \\
\hline 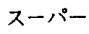 & & & 34 & 8 & & 3 \\
\hline & $(79.6)$ & 5. 7) & .3) & & 5] & [37.5] \\
\hline 工场目庫 & 57 & 15 & 18 & 24 & 17 & 7 \\
\hline & (65.9) & & 1.2 & $(26.0$ & {$[10.8]$} & {$[29.2$} \\
\hline
\end{tabular}

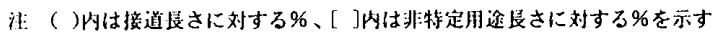

場・倉庫では作業用地の割合が最も高い。

(2)接道部利用と非特定用途長さ

表-3について接道長さに対する接道空地長さの割合を 施設用途別にみると、公園・運動場の $98.1 \%$ から工場・ 倉廍の $65.9 \%$ までに及んでいる。

接道空地長さの内訳は、スーパーでは進入口長さの割 合が最も高く、その他の施設では公園・運動場を最高と して非特定用途長さの割合が最も高くなっている。

(3)まとめ

敷地面積に対する非建ぺい地の割合は、幼・保有園、 病院、文化・休育、社寺、そ机に户建住宅では、非特定 用途地が高く、学校や公園・運動場では、運動場の割合 が最も高い。又、住宅団地やスーパーでは、交通用地が 高く、工場・倉庫では作業用地の割合が最も高い。

接道長さに対する接道空地長さの割合は、スーパーで は進入口長さが高く、その他の施設用途では、非特定用
途長さの割合が最む高くなっている。

以上のように、施設用途別に施設内土地利用は多様で ある。従ってここでは、施設用途別に緑化可能面積、接 道緑化可能長さを検討する。

3.2 緑化可能面積と接道緑化可能長さ

さて、非特定用途地は、緑被部分と空地部分から成る。 この空地部分には、建物や各種用地周辺の緩㣫、保守等 のために必要となる緑化不可能な部分としての必要空地

(幅䄪1程度) が含まれる。これらを差し引いた残りの 部分は、敷地や建物の形状等との関係で生じた半端な土 地であったり、計画予定のない空地である場合のほか、 計画担保地である場合等も含んでいる。しかし、本調査 では大規模施設内の土地利用は、施設固有の多くの条件 によって規定され、この残りの部分の緑化の詳紐な動向 を捉えることは困難であった。このため、ここでは調査 時点におけるこの残りの部分を緑化可能面積として統計 的に処理した。

勿論、特定用途地の中でも、駐車場として利用されて いる交通用地や、資材置場となっている作業用地などに おいても今後景観上緑化が必要な部分が存在すると考え られる。しかし本調査で明らかにすることは出来なかっ た。これらについては、今後の課題として残されている。

このようにして、本節では敷地面積に対する非特定用 途地の割合と敷地面積に対する緑被部分の割合の統計的 処理を行い、大規模施設内の緑化可能面積を推計した。 (1)緑化可能面積の画定

図-6の実線は、サンプルの回㷌直線を示し、一点鎖線 の対角線（Y=X）は、非特定用途地が $100 \%$ 緑被部分とな った状態を表している。

ここで、分布図の中で緑被部分の值が最大となってい るサンプルを結び破線を得る。この直線は、各施設用途 の既存施設の中では緑化の上限を示していると考える。 これを敷地緑化可能直線とした。すると、敷地緑化可能 直線と対角線との間隔は埋まることのない空地、つまり、 建物周辺などの必要空地であると考えられる。さらに、 施設用途ごとの緑化可能面積がどれ程存在するかを考え ると、敷地緑化可能直線と回㷌直線との間の部分が、当 該施設用途の緑化可能面積を表していると考える。おく まで、現況の敷地内土地利用の統計分析から考えて、少 なくともこの部分は緑化可能と判断している。

なお、緑化可能值線式の範囲は、分布図に表されたテ 一夕の範囲之考えており、回㷌直線の定数項は、緑化可 能直線の X切片に合わせて求めている。

では、以上の内容を具体的にサンプルの土地利用との 関係に於いて確認してみよう。図一7は、緑化可能直線上 の施設 (図-6のA点) と、緑化可能直線から離れた施設

（図-6のB点）の施設利用実態を例示している。紙面の 都合により、5 種類の施設用途について例示しており、 

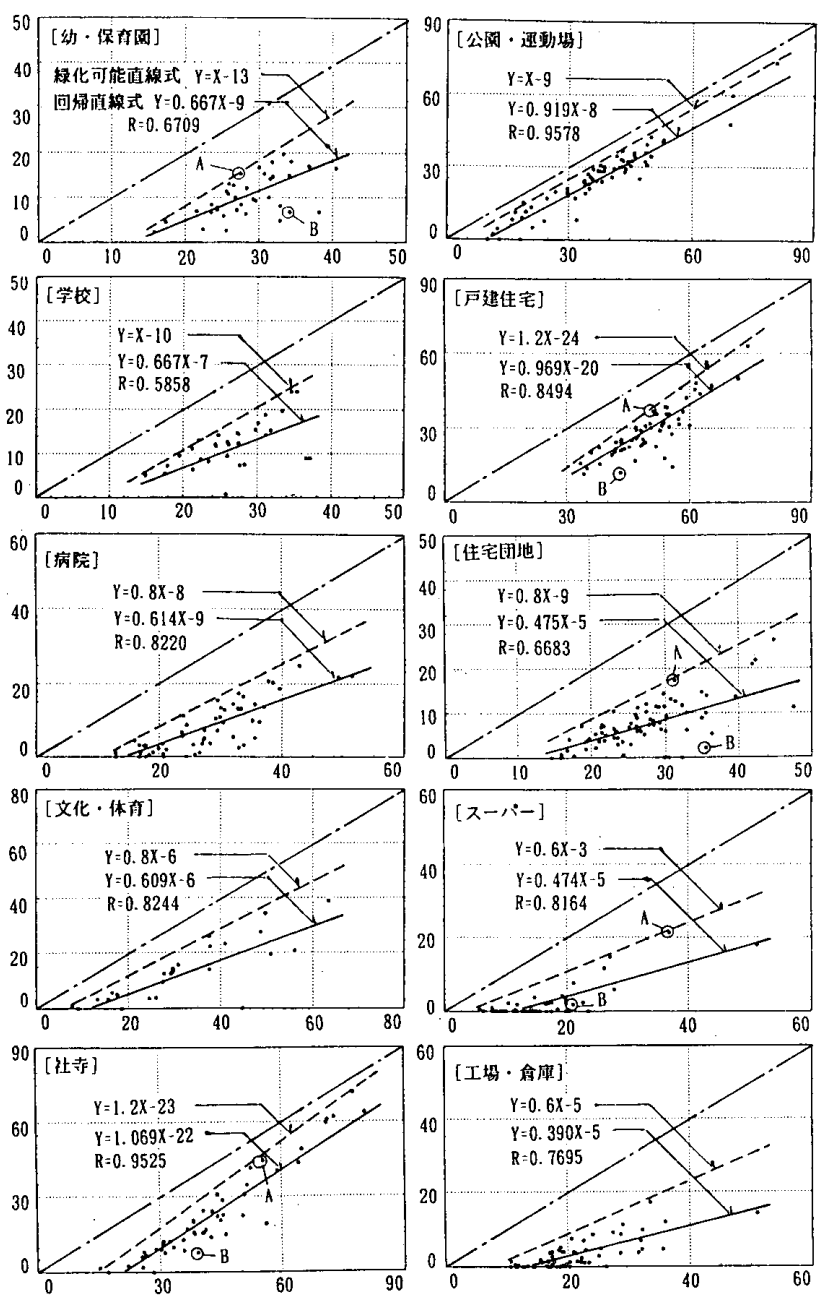

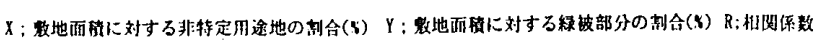
図-6 數地緑化可能直線図

緑化可能面積が認められない施設は左欄に、緑化可能面 積が認められる施設は右欄に示している。図中の括弧内 数字は、非特定用途地に対する緑被部分の割合（\%)を 表している。

(2)現況調查による確認

まず、緑化可能面積が認められない施設の幼・保育園 の場合については、S 幼稚園を見ると、建築用地、交通、 作業等用地（通路、運動場等）以外の非特定用途地のう ち緑被部分を除いた空地部分は、建築用地周辺に幅約 $1 \mathrm{~m}$ の必要空地としてのみ残されており、必要空地以外の非 特定用途地が $100 \%$ 緑化されている。社寺の事例で、 $\mathrm{H}$ 神 社の境内は、くす、いちょう、杉等の樹高 $20 \mathrm{~m}$ 以上の高木 が多く、東側では緑に被われた林内の通路に闹や社が並 んでいる。参道周辺の緑に被われていない部分や拝殿前 の部分は参拝客の行き交う砂敷きの広場となっており、 余すところなく使用さ机ている。北側の車寄せはコンク リートの舖装がなされ、駐車場は社務所用として藤棚の 下まで利用されている。次に、戸建住宅の例では、N邸 は東側を川に接しており、川沿いの庭園には、むくの木、 もちの木、まき、松等の高木が茂り、芝生の中には中低
木も多い。北側のアプローチは、舗装した通路を除いて 緑で被われている。又、住宅団地の事例で、S 社宅は、 遊び場や、芝生の庭園部分も端部までよく利用され、未 緑化の非特定用途地は認められない。スーパーの事例で、 Nレストランは、道路側に敷地境界まで舗装した駐車場 を持ち、南側には店内から見渡すことの出来る庭園が設 けられている。西側はサービススペースに使われ、未緑 化の非特定用途地は認められない。図中の庭園用地等に 今後植栽される可能性があるが、ここでは土地利用の現 況に従って、すでに緑化されていると見なした。以上の ように、A点の施設では、これ以上の新たな緑化可能面 積が認められないことが分る。

一方、B点の C 保育園では、東側駐車場と南側運動場 との間に、特定の用途が見られない雑草の生えた裸地が あり、未緑化の空地（緑化可能面積）が存在している。 建物の北西側空地はコンクリートで舖装されており、サ 一ビスのための必要空地である。

$S$ 寺院の場合では、庫裏の裏手にかって建物が存在し たと見られる雑草の繁る空地部分があり、H期では、北 側隣地境界部分に裸地のままで、特定の用途が見られな い空地部分が存在しており、これらは緑化可能な空地と して存在している。

又、Y社宅は、官庁の中層集合住宅団地で數地にかな りの余裕があり、棟間空地も自動車の不法乗り入れに利 用していて、遊び場としての利用も見られず、長期にわ たって特定の用途が見られない部分である。H建材店で は、東側道路との境界部分に、必要空地を超える植栽の ない幅員約 $2.5 \mathrm{~m} の$ 空地があり、緑化可能面積と判断した。 西側境界部分は、道路際のまきの木の周囲を除いて全面 アスファルト舗装で固められ、駐車や荷捌き、資材置場 としてフルに利用されている。

このように、緑化可能面積の存在の要件はまちまちで あるが、A 点の施設に較へて B 点の施設は極端に低い緑 被部分の割合（図中の括弧内の数字）を示している。そ して、これらの内容を示した分布図（図-6）は、回㷌分 析の結果非特定用途地の割合と緑被部分の割合がかなり 高い相関を示し、施設用途別の統計的解析の妥当性を明 らかにしている。

(3)緑化可能面積の推計

そこで、図ー6を用いて緑化可能面積の推計を行って見 よう。サンプルには、例として図-7のC保有園をとりあ げる。

計測值（敷地面積 $1417 \mathrm{~m}^{2}$ 、非特定用途地の割合 $34.3 \%$ 、 緑被部分の割合 $6.7 \%$ ）より、緑化可能直線式を用いて、 非特定用途地の割合 $34.3 \%$ 場合の敷地緑化可能直線上 の緑被部分の割合を求めると、 $21.3 \%$ が得られる。必要 空地の割合は、対角線と敷地緑化可能直線との間隔 13.0 $\%$ となり、緑化可能面積の割合は、敷地緑化可能直線と 


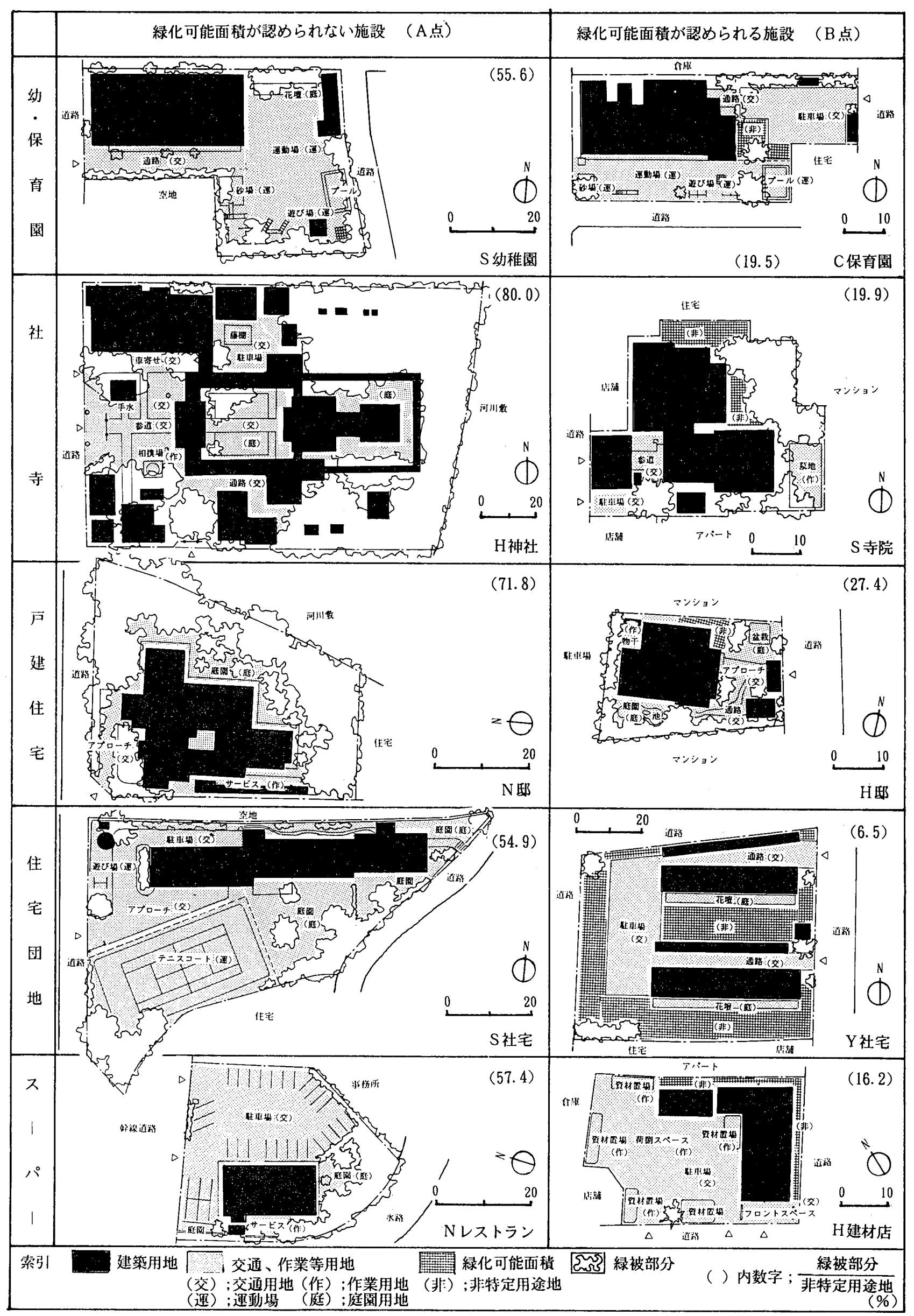

図 -7 施設内土地利用と緑化可能面䅡 
$\mathrm{B}$ 点との間隔 $14.6 \%$ として求められる。これらの数值に 敷地面積 $1417 \mathrm{~m}^{2}$ を乗じると、必要空地 $184 \mathrm{~m}^{2}$ 、緑化可能面 積 $207 \mathrm{~m}^{2}$ を求めることが出来る。

このように、大規模施設の必要空地及び緑化可能面積 は、緑化可能直線式により推定することが出来る。そこ で、各施設用途の平均の非特定用途地の值を用いて、施 設用途別の緑化可能面積、及び必要空地の割合をグラフ から読み取る。表-4はこれらの結果をまとめたもので、 緑化可能面積の割合は、戸建住宅 (7.7\%) や病院（6.2 \%)、幼・保育園、学校（5.8\%）で高く、公園・運動場 (1.6\%)、スーパー（3.6\%）で低い值となっているが、 中でも敷地規模の大きな学校に於ける今後の緑化が期待 される。

又、必要空地は、住宅団地（14.5\%）、戸建住宅（13.9 $\%) 、$ 病院 $(13.5 \%)$ 、社寺 $(13.4 \%)$ 等が高く、スー パー（8.2\%）、公園・運動場（9.0\%）で低くなること が分る。

(4)接道緑化可能長さの考察

接道部の非特定用途長さは、当該部分が現状で建築用 地や交通、作業用地等に利用されていない空地、或いは緑 被地であることを意味しており、この空地は接道部の緑 化可能長さであると考えた。この空地の形態は、塀やフ エンスなど接道部分の境界の棈造物によって影響される ことも考えられるが、その接道部分の敷地 2 以以内の空地 部分では、緑化が可能であると判断した。

勿論、接道施設長さや作業用地等長さの部分にも現実 には緑被部分が存在する。しかし、これらの土地利用は 施設用途固有の条件に支配されるもので、本研究の接道 緑化可能長さの対象外亡して、今後の課題と考えている。

表一3には、接道緑化可能長さの計測結果を施設用途別 に示した。又、表-4には、接道長さに対する接道緑化可 能長さの割合を示した。

表一3に於いて、非特定用途長さに対する接道緑化可能 長さの平均值は、最大 $37.5 \%$ （スーパー）から最小 $5.3 \%$ （公園・運動場）までとなり、一般に低い值を示してい る。しかし、非特定用途長さに対する緑被部分長さの割 合で見ると、スーパー（62.5\%）や工場・倉庫（70.8\%） でやや低い値になっているが、公園・運動場（94.7\%）、 F建住宅 $(94.5 \%) 、$ 社寺 $(93.8 \%) 、$ 学校 $(93.2 \%)$ 等 では高い値を示し、これらの施設での接道緑化の完成度 が高いことを明らかにしている。

なお、接道緑化可能長さと接道長さとの関係について 施設用途別に回㷌分析を行った結果、相関係数はかなり 低い值となり、接道長さに対する接道緑化可能長さの相 関が得られなかった。又、接道部分の利用と接道辺数、 接道タイプ等との関係についても調查分析を行ったが、 いずれも相関が認められなかった。

(5)まとめ
表-4 緑化可能面積、接道緑化可能長さ等平均值

\begin{tabular}{|c|c|c|c|c|c|c|}
\hline & \multicolumn{5}{|c|}{ 緑化可能湴酳等 } & \multirow[b]{2}{*}{$\begin{array}{l}\text { D } \\
\text { 接道緑化 } \\
\text { 诃能唇さ }\end{array}$} \\
\hline & $\begin{array}{l}\text { A } \\
\text { 非特䇥 } \\
\text { 用金地 }\end{array}$ & $\begin{array}{l}\text { B } \\
\text { 緑被颗 } \\
\text { 火做 }\end{array}$ & $\begin{array}{l}\mathrm{C} \\
\text { 緑被平 } \\
\text { 均値 }\end{array}$ & 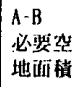 & $\begin{array}{l}B-C \\
\text { 粶化可 } \\
\text { 能酒i础 }\end{array}$ & \\
\hline 㭃保面翻 & 29.5 & 16.5 & 10.7 & 13.0 & 5.8 & 4.8 \\
\hline 学校 & 26.3 & 16.3 & 10.5 & 10.0 & 5.8 & 5.3 \\
\hline 院 & 27.6 & 14.1 & 7.9 & 13.5 & 6. 2 & 7.7 \\
\hline 文化体肖 & 26.7 & 15.4 & 10.3 & 11.3 & 5. 1 & 3.6 \\
\hline & 48.0 & 34.6 & 29.3 & 13.4 & 5.3 & 3.2 \\
\hline 公困運動 & 31.6 & 22.6 & 21.0 & 9.0 & l. 6 & 4. 4 \\
\hline 当延住宅 & 50.4 & 36.5 & 28.8 & 13.9 & 7.7 & 3.7 \\
\hline 住宅团地 & 27.5 & 13.0 & 8.1 & 14.5 & 4. 9 & 6.0 \\
\hline スーパー & 13.0 & 4.8 & 1.2 & 8.2 & 3.6 & 3.1 \\
\hline 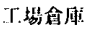 & 18.8 & 6.3 & 2.3 & 12.5 & 4. 0 & 7.9 \\
\hline
\end{tabular}

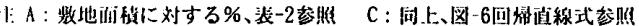

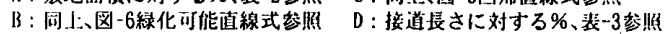

大規模施設の敷地面積に対する緑化可能面積の割合は 図-6に於ける各点と敷地緑化可能直線との間隔で求め、 建物周辺などの必要空地の割合は、敷地緑化可能直線と 対角線との間隔で求めた。又、接道緑化可能長さは、非 特定用途長さの内の緑被部分長さを測定して求めた。

緑化可能面積の割合は、戸建住宅や病院、幼 - 保有園、 学校で高く、公園・運動場、スーパーで低い值を示して いる。

4 施設管理者の意識と緑化の度合いについて

これまで、施設の緑化可能面積と接道緑化可能長さが どのように存在しているかを見たが、本節では、施設の 緑化が当該施設の管理者の意識とどのように関わってい るかを明らかにすることとした。この為、大規模施設調 查で対象とした施設の中からアンケートの可能な施設を 選び、施設管理者（施設の長、叉はそれに代わる立場の 人）に対して、施設緑化等に関する意識調查を行った。

\section{1 意識調査の概要}

調查は1990年10月に留置式で行い、有効回答375件を得 た。施設用途等を考虑してこれを幼稚園・学校（54件）、 病院・文化体有（57件）、社寺・戸建住宅(89件)、スー パー・工場（スーパー、工場・倉庫など175件）の 4 グル ープに分けて別々に集計した。表一5は意識調査における 主要 10 項目の設問の内容と、その単純集計の結果を示し ている。

何らかの構内緑化運動に取り組んでいる割合は、幼稚 園 - 学校 $(87.0 \%)$ 、病院 · 文化体有 $(71.9 \%)$ 、社寺 - 戸建住宅（50.6\%）、スーパー・工場（40.0\%）の順 序になっている。また、「緑化の問題点」で、スーパー ・工場は $65.7 \%$ が「緑化のスペースがない」と答えてい る。また、「接道緑化の問題点」で、スーパー・工場の $70.9 \%$ は通路部分にあたるから」或いは「駐車スペー スだから」を理由に、緑化が困難であると述べて、敷地 利用の特殊性を見せている。 
表-5 意識調查単純集計

\begin{tabular}{|c|c|c|c|c|c|c|c|c|c|}
\hline \multirow{2}{*}{$\begin{array}{l}\text { 要 } \\
\text { 以 }\end{array}$} & \multirow{2}{*}{ 力 $\bar{\top} y$ J -} & \multicolumn{2}{|c|}{ 幼排・学校 } & \multicolumn{2}{|c|}{ 抦院 - 文化 } & \multicolumn{2}{|c|}{ 外寺・分建 } & \multicolumn{2}{|c|}{$x-n^{0}-$ 工㘿 } \\
\hline & & $\begin{array}{l}\text { 反心 } \\
\text { 数 }\end{array}$ & 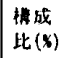 & $\begin{array}{l}\text { 反应 } \\
\text { 数 }\end{array}$ & $\begin{array}{l}\text { 掅成 } \\
\text { 比( }(x)\end{array}$ & $\begin{array}{l}\text { 区店 } \\
\text { 数 }\end{array}$ & $\begin{array}{l}\text { 棈战 } \\
\text { 比( }\end{array}$ & $\begin{array}{l}\text { 反心 } \\
\text { 数 }\end{array}$ & $\begin{array}{l}\text { 情成 } \\
\text { 比(S) }\end{array}$ \\
\hline 㥏化 & Al 排進和较（但当）設那 & 18 & 33.3 & 0 & 0 & 0 & 0 & 6 & 3.4 \\
\hline 内遇 & A2 緑化指:進に心挷ている & 29 & 53.7 & 41 & 71.9 & 45 & 50.6 & 64 & 36.6 \\
\hline 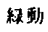 & $A 3$ 行っていない & 7 & 13.0 & 16 & 28. 1 & 44 & 49.4 & 105 & 60.0 \\
\hline 級ど & AI 道路治いの教地境界部 & 5 & 9.3 & 10 & 17.5 & 12 & 13.5 & 52 & 29.7 \\
\hline 化こ & A2 その他の㪙地境界部分 & 0 & 0 & 0 & 0 & 4 & 4.5 & 19 & 10.9 \\
\hline のか & A3 㩆地全:般 & 31 & 57.4 & 33 & 57.9 & 43 & 48.3 & 31 & 17.7 \\
\hline 重 & A4 高木を柱休にしている & 3 & 5.5 & 0 & 0 & 12 & 13.5 & 9 & 5.1 \\
\hline 点 & A5 花きを玨休にしている & 13 & 24.1 & 5 & 8.8 & 7 & 7.9 & 21 & 12.0 \\
\hline は & A6 その他 & 2 & 3.7 & 9 & 15.8 & 11 & 12.3 & 43 & 24.6 \\
\hline 綪题 & Al 粶化のスペースがない & 22 & 40.7 & 20 & 35.1 & 24 & 27.0 & 115 & 65.7 \\
\hline 化点 & 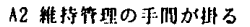 & 13 & 24.1 & 10 & 17.5 & 28 & 31.5 & 29 & 16.6 \\
\hline の & A3 維持管理の 学用が掛る & 14 & 25.9 & 27 & 47.4 & 22 & 24.7 & 20 & 11.4 \\
\hline 明 & $A 4$ その仙 & 5 & 9.3 & 0 & 0 & 15 & 16.8 & 11 & 6. 3 \\
\hline 施の & AI 必要と思j & 48 & 88.9 & 47 & 82.5 & 67 & 75.3 & 102 & 58.3 \\
\hline 設必 & A2 必要だがペー & 6 & 11.1 & 10 & 17.5 & 10 & 11.2 & 63 & 36.0 \\
\hline 悢要 & A3 少からない & 0 & 0 & 0 & 0 & 12 & 13.5 & 10 & 5.7 \\
\hline 化性 & & & & & & & & & \\
\hline 施化 & A1 周辽の是制形成に有効 & 10 & 18.5 & 34 & 59.6 & 44 & 49.4 & 106 & 60.6 \\
\hline 設の & 12 当力の建物を引立てる & 0 & 0 & 6 & 10.5 & 11 & 12.3 & 21 & 12.0 \\
\hline 内密 & ヘ3 部内の目を淤しませる & 23 & 42.6 & 13 & 22.8 & 20 & 22.5 & 28 & 16.0 \\
\hline 楺䉝 & $\wedge 4$ その他 & 21 & 38.9 & 4 & 7.0 & 14 & 15.7 & 20 & 11.4 \\
\hline 粶の & Al 施設の籺を見せる & 21 & 38.9 & 27 & 47.4 & 44 & 49.4 & 68 & 38.9 \\
\hline の际 & 12 部分的に木尼に解放す & 4 & 7.4 & 0 & 0 & 0 & 0 & 5 & 2.9 \\
\hline 頁度 & ^3 杰民の意見を考度する & 11 & 20.4 & 11 & 19.3 & 13 & 14.6 & 27 & 15.4 \\
\hline 献 & A4 その他 & 18 & 33.3 & 19 & 33.3 & 32 & 36.0 & 75 & 42.9 \\
\hline 接粈 & 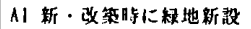 & 4 & 7.4 & 8 & 14.0 & 8 & 9.0 & 21 & 12.0 \\
\hline 道化 & A2 场を纵垣や版込にする & 14 & 25.9 & 22 & 38.6 & 26 & 29.2 & 55 & 31.4 \\
\hline 部治 & A3 物をフ & 20 & 37.0 & 7 & 12.3 & 7 & 7.9 & 20 & 11.4 \\
\hline 分打 & A4 外から胃える品木とす & 6 & 11.1 & 4 & 7.0 & 25 & 28.1 & 21 & 12.0 \\
\hline の & A5 その他 & 10 & 18.5 & 16 & 28.1 & 23 & 25.8 & 58 & 33.1 \\
\hline 接の & A1 通路部外にあたろから & 13 & 24.1 & 8 & 14.0 & 13 & 14.6 & 72 & 41.1 \\
\hline 进闍 & 12 作策 & 8 & 14.8 & 3 & 5. 3 & 0 & 0 & 4 & 2.3 \\
\hline 棣题 & A3 铌東スベースだから & 2 & 3.7 & 10 & 17.5 & 17 & 19. 1 & 52 & 29.7 \\
\hline 化点 & A4 その他 & 31 & 57.4 & 36 & 63.2 & 59 & 66.3 & 47 & 26.9 \\
\hline 都の & A1国、思市などの公有地 & 19 & 35.2 & 21 & 36.8 & 38 & 42.7 & 75 & 42.9 \\
\hline 沙磪 & 12 彷路榯 & 9 & 16. 7 & 11 & 19. 3 & 10 & 11.2 & 36 & 20.6 \\
\hline の保 & A3 一定规掑以 & 8 & 14.8 & 8 & 14.0 & 10 & 11.2 & 16 & 9.1 \\
\hline 絊 & 14 緑化可能方全土地 & 18 & 33.3 & 17 & 29.8 & 25 & 28.1 & 39 & 22.3 \\
\hline 地 & A5 その他 & 0 & 0 & 0 & 0 & 6 & 6.7 & 9 & 5.1 \\
\hline 地 & 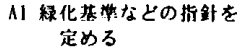 & 23 & 42.6 & 26 & 45.6 & 28 & 31.5 & 91 & 52.0 \\
\hline 線 & 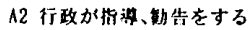 & 0 & 0 & 0 & 0 & 7 & 7.9 & 9 & 5.1 \\
\hline 化 & 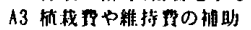 & 16 & 29.6 & 9 & 15.8 & 12 & 13.5 & 22 & 12.6 \\
\hline の & 14 粔化遇動で土地沂有者 & 5 & 9.3 & 14 & 24.6 & 21 & 23.6 & 13 & 7.4 \\
\hline ' & & & & & & & & & \\
\hline 法 & A5 作尼と管呗体制を作る & 7 & 13.0 & 8 & 14.0 & 6 & 6.7 & 16 & 9.1 \\
\hline & A6 & 3 & 5.5 & 0 & 0 & 15 & 16.8 & 24 & 13. 7 \\
\hline
\end{tabular}

\section{2 施設管理者の意識と緑化の度合いの関係}

上記のデータをもとに、管理者の意識と施設緑化の関 係を捉えるために、数量化 I 類分析を行った。分析での 外的基準としては、緑被面積の割合 (非特定用途地面積 に対する緑被面積の割合）を採用した。

又、同様に接道部分の緑化については、接道緑被長さ の割合（非特定用途長さに対する接道緑被長さの割合） を外的基準に採用した。分析の結果は、表-6及び表-7に まとめた。重相関係数は最高が0.8647で、最低は、0.4174 となっている。

\section{(1)敷地緑化に対する管理者の意諳}

まず表-6をみると、緑被面積の割合に影響を与える分 析で社寺・戸建住宅、及びスーパー・工場のグループで は、レンジが最も大きくなる要因は共に「緑化の重点は どこか」（寄与率各 $19.2 \% 、 23.2 \%$ ) であり、カテゴリ 一では「高木を主体にしている」との答えが緑被面積の
表-6 緑被面積の割合と意識調查の分析

\begin{tabular}{|c|c|c|c|c|c|c|c|c|c|}
\hline \multirow{3}{*}{$\begin{array}{l}\text { 要 } \\
\text { 内 }\end{array}$} & \multirow{3}{*}{$\begin{array}{l}力 \\
\bar{\tau} \\
y \\
y \\
1\end{array}$} & \multicolumn{8}{|c|}{ 線被面椟の剽合 } \\
\hline & & \multicolumn{2}{|c|}{ 幼推圆・学校 } & \multicolumn{2}{|c|}{ 病院 - 又化体南 } & \multicolumn{2}{|c|}{ 社寺・F建倠宅 } & \multicolumn{2}{|c|}{ スーパー・丁場 } \\
\hline & & $x \supset 7$ & 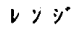 & $x \sqsupset 7$ & レンジ & $x I 3$ & レンジ & 237 & レッジ \\
\hline $\begin{array}{l}\text { 樌化 } \\
\text { 内通 } \\
\text { 緑動 }\end{array}$ & $\begin{array}{l}\mathrm{A} 1 \\
\mathrm{~A} 2 \\
\mathrm{~A} 3\end{array}$ & $\begin{array}{r}0.006 \\
-0.017 \\
0.054\end{array}$ & $\begin{array}{r}0.070 \\
(7.5) \\
\text { (7) }\end{array}$ & $\begin{array}{c}\ldots \ldots \\
-0.022 \\
0.058\end{array}$ & $\begin{array}{c}0.080 \\
(6.5) \\
\text { (7) }\end{array}$ & $\begin{array}{c}\ldots . . \\
-0.045 \\
0.046\end{array}$ & $\begin{array}{c}0.090 \\
(6.4) \\
(8)\end{array}$ & $\begin{array}{r}-0.016 \\
0.045 \\
-0.027\end{array}$ & $\begin{array}{c}0.072 \\
(8.0) \\
(7)\end{array}$ \\
\hline $\begin{array}{l}\text { 緑ど } \\
\text { 化こ } \\
\text { のか } \\
\text { 蒠 } \\
\text { 点 } \\
\text { は }\end{array}$ & $\begin{array}{l}A 1 \\
\Lambda 2 \\
A 3 \\
\Lambda 4 \\
\Lambda 5 \\
A 6\end{array}$ & $\begin{array}{r}-0.076 \\
\ldots \ldots . . \\
0.021 \\
-0.079 \\
-0.026 \\
0.154\end{array}$ & $\begin{array}{r}0.233 \\
(24.7) \\
\text { (1) }\end{array}$ & $\begin{array}{c}0.015 \\
\ldots \ldots . \\
0.016 \\
\ldots \ldots . \\
-0.005 \\
-0.072\end{array}$ & $\begin{array}{c}0.088 \\
(7.1) \\
\text { (6) }\end{array}$ & $\begin{array}{r}-0.110 \\
-0.201 \\
0.034 \\
0.068 \\
-0.022 \\
-0.002\end{array}$ & $\begin{array}{r}0.270 \\
(19.2) \\
\text { (1) }\end{array}$ & $\begin{array}{r}0.003 \\
-0.066 \\
-0.013 \\
0.144 \\
0.018 \\
-0.005\end{array}$ & $\begin{array}{r}0.209 \\
(23.2) \\
\text { (1) }\end{array}$ \\
\hline $\begin{array}{l}\text { 緑题 } \\
\text { 化点 } \\
の \\
\text { [䦌 }\end{array}$ & $\begin{array}{l}A 1 \\
A 2 \\
A 3 \\
A 4\end{array}$ & $\begin{array}{r}-0.065 \\
0.034 \\
0.071 \\
0.002\end{array}$ & $\begin{array}{r}0.136 \\
(14.6) \\
\text { (2) }\end{array}$ & $\begin{array}{c}-0.092 \\
-0.009 \\
0.072 \\
\cdots \cdots\end{array}$ & $\begin{array}{r}0.164 \\
(13.2) \\
\text { (3) }\end{array}$ & $\begin{array}{r}0.026 \\
-0.019 \\
-0.041 \\
0.055\end{array}$ & $\begin{array}{c}0.095 \\
(6.8) \\
(7)\end{array}$ & $\begin{array}{r}-0.012 \\
0.036 \\
0.047 \\
-0.053\end{array}$ & $\begin{array}{r}0.100 \\
(11.1) \\
\text { (5) }\end{array}$ \\
\hline $\begin{array}{l}\text { 施の } \\
\text { 設必 } \\
\text { 緑要 } \\
\text { 化推 }\end{array}$ & $\begin{array}{l}\mathrm{A} 1 \\
\mathrm{~A} 2 \\
\mathrm{~A} 3\end{array}$ & $\begin{array}{c}-0.007 \\
0.054 \\
\ldots \ldots\end{array}$ & $\begin{array}{c}0.061 \\
(6.5) \\
\text { (8) }\end{array}$ & $\begin{array}{c}-0.020 \\
0.095 \\
\ldots \ldots .\end{array}$ & $\begin{array}{c}0.115 \\
(9.3) \\
\text { (4) }\end{array}$ & $\begin{array}{r}0.005 \\
-0.094 \\
0.053\end{array}$ & $\begin{array}{r}0.147 \\
(10.5) \\
(5)\end{array}$ & $\begin{array}{r}0.006 \\
-0.009 \\
-0.006\end{array}$ & $\begin{array}{c}0.015 \\
(1.7) \\
\text { (8) }\end{array}$ \\
\hline $\begin{array}{l}\text { 施化 } \\
\text { 設の } \\
\text { 内意 } \\
\text { 緑䣡 }\end{array}$ & $\begin{array}{l}A 1 \\
A 2 \\
A 3 \\
A 4\end{array}$ & $\begin{array}{c}0.049 \\
\ldots \ldots \\
0.028 \\
-0.055\end{array}$ & $\begin{array}{r}0.104 \\
(11.1) \\
\text { (5) }\end{array}$ & $\begin{array}{r}0.003 \\
-0.059 \\
-0.083 \\
0.329\end{array}$ & $\begin{array}{r}0.412 \\
(33.2) \\
\text { (1) }\end{array}$ & $\begin{array}{r}-0.004 \\
-0.091 \\
-0.044 \\
0.146\end{array}$ & $\begin{array}{r}0.237 \\
(16.9) \\
\text { (3) }\end{array}$ & $\begin{array}{r}0.013 \\
0.042 \\
-0.042 \\
-0.053\end{array}$ & $\begin{array}{r}0.096 \\
(10.6) \\
\text { (6) }\end{array}$ \\
\hline $\begin{array}{l}\text { 粶の } \\
\text { の限 } \\
\text { 面度 } \\
\text { 㣮 }\end{array}$ & $\begin{array}{l}\mathrm{A} 1 \\
\mathrm{~A} 2 \\
\mathrm{~A} 3 \\
\mathrm{~A} 4\end{array}$ & $\begin{array}{r}0.056 \\
0.044 \\
0.010 \\
0.050\end{array}$ & $\begin{array}{r}0.106 \\
(11.3) \\
\text { (4) }\end{array}$ & $\begin{array}{c}0.040 \\
\cdots \cdots \\
0.024 \\
-0.071\end{array}$ & $\begin{array}{c}0.111 \\
(9.0) \\
(5)\end{array}$ & $\begin{array}{c}0.065 \\
\ldots \ldots \\
-0.063 \\
-0.064\end{array}$ & $\begin{array}{r}0.128 \\
(9.1) \\
\text { (6) }\end{array}$ & $\begin{array}{r}-0.035 \\
0.113 \\
0.009 \\
0.022\end{array}$ & $\begin{array}{r}0.148 \\
(16.4) \\
\text { (3) }\end{array}$ \\
\hline $\begin{array}{l}\text { 部の } \\
\text { 市研 } \\
\text { の保 } \\
\text { 緑 } \\
\text { 地 }\end{array}$ & $\begin{array}{l}A 1 \\
A 2 \\
A 3 \\
A 4 \\
A 5\end{array}$ & $\begin{array}{r}-0.025 \\
0.068 \\
-0.015 \\
-0.001 \\
\cdots \cdots\end{array}$ & $\begin{array}{c}0.093 \\
(9.9) \\
\text { (6) }\end{array}$ & $\begin{array}{r}0.008 \\
-0.014 \\
-0.046 \\
0.020 \\
\cdots \cdots\end{array}$ & $\begin{array}{c}0.066 \\
(5.3) \\
\text { (B) }\end{array}$ & $\begin{array}{r}-0.050 \\
0.141 \\
0.187 \\
-0.054 \\
-0.001\end{array}$ & $\begin{array}{r}0.241 \\
(17.2) \\
\text { (2) }\end{array}$ & $\begin{array}{r}0.010 \\
-0.026 \\
0.023 \\
0.024 \\
-0.125\end{array}$ & $\begin{array}{r}0.149 \\
(16.5) \\
\text { (2) }\end{array}$ \\
\hline $\begin{array}{l}\text { 地法 } \\
\text { 域 } \\
\text { 粶 } \\
\text { 化 } \\
\text { の } \\
\text { 方 }\end{array}$ & $\begin{array}{l}A 1 \\
A 2 \\
A 3 \\
A 4 \\
A 5 \\
A 6\end{array}$ & $\begin{array}{c}0.042 \\
\ldots \ldots \\
-0.027 \\
-0.091 \\
0.024 \\
-0.085\end{array}$ & $\begin{array}{r}0.133 \\
(14.2) \\
\text { (3) }\end{array}$ & $\begin{array}{c}0.005 \\
\ldots \ldots . \\
-0.139 \\
0.064 \\
0.027 \\
\cdots \cdots\end{array}$ & $\begin{array}{r}0.204 \\
(16.4) \\
\text { (2) }\end{array}$ & $\begin{array}{r}-0.054 \\
-0.080 \\
0.116 \\
-0.014 \\
0.001 \\
0.065\end{array}$ & $\begin{array}{r}0.196 \\
(14.0) \\
\text { (4) }\end{array}$ & $\begin{array}{r}-0.011 \\
-0.027 \\
0.009 \\
0.047 \\
-0.056 \\
0.056\end{array}$ & $\begin{array}{r}0.112 \\
(12.4) \\
\text { (4) }\end{array}$ \\
\hline $\begin{array}{l}\text { 重机 } \\
\text { 決定 }\end{array}$ & & & $\begin{array}{l}0.6337 \\
0.4016\end{array}$ & & $\begin{array}{l}0.6961 \\
0.4845\end{array}$ & & $\begin{array}{l}0.6115 \\
0.3740\end{array}$ & & $\begin{array}{l}0.4174 \\
0.1742\end{array}$ \\
\hline
\end{tabular}

非 ( ) ; 青与深 (3)；顼位

割合の増化に最も寄与している。第 2 位の要因には、「都 市の緑地の確保」てで、カテコリーでは「一定規模以上の 土地」となっている。

これらのことから、社寺・戸建住宅やスーパー・エ場 など、民間系の施設で、緑被面積の割合の高い施設の管 理者は、緑化の重点に高木の植栽をあげ、都市緑地の確 保の方法としては「一定規模以上の土地」を対象とする と考えていることが分った。

幼稚園・学校の管理者では、要因の第 1 位は「緑化の 重点はどこか」（寄与率 $24.7 \%)$ であり、カテコリーの 「敷地全般」となっている。第 2 位の要因は、「緑化の 問題点」で、カテゴリーでは「維持管理の費用がかかる」 となっている。

また、病院・文化体育では、要因の第 1 位に「施設内 緑化の意義」（寄与率33.2\%）があげられ、カテゴリー では「部内の目を楽しませる」となっている。

これらのことから、幼稚園・学校、病院・文化体育な ど公共系の施設で緑被面積の割合の高い施設の管理者は、 
表-7 接道緑被長さの割合と意識調查の分析

\begin{tabular}{|c|c|c|c|c|c|c|c|c|c|}
\hline \multirow{3}{*}{ 要 } & \multirow{3}{*}{\begin{tabular}{l|} 
力 \\
$\bar{\tau}$ \\
7 \\
11 \\
1
\end{tabular}} & \multicolumn{8}{|c|}{ 接道緑被最さの剂命 } \\
\hline & & \multicolumn{2}{|c|}{ 㭃秘囷・学校 } & \multicolumn{2}{|c|}{ 病院·文化体育 } & \multicolumn{2}{|c|}{ 社寺·戸建住宅 } & \multicolumn{2}{|c|}{ スーパー・工場 } \\
\hline & & 2 I & レンジ & 213 & Vッジ & $x=7$ & レッシ・ & $x=7$ & レッシ \\
\hline $\begin{array}{l}\text { 榐化 } \\
\text { 队運 } \\
\text { 緑動 }\end{array}$ & $\mid \begin{array}{l}11 \\
\Lambda 2 \\
\Lambda 3\end{array}$ & $\begin{array}{r}-0.183 \\
0.014 \\
0.411\end{array}$ & $\begin{array}{r}0.593 \\
(8.6) \\
\text { (6) }\end{array}$ & \begin{tabular}{|r|r|}
0.031 \\
-0.079
\end{tabular} & $\begin{array}{c}0.110 \\
(3.9) \\
(9)\end{array}$ & $\begin{array}{r}-0.032 \\
0.033\end{array}$ & $\begin{array}{c}0.065 \\
(2.1) \\
\text { (9) }\end{array}$ & $\begin{array}{r}0.206 \\
0.048 \\
-0.041\end{array}$ & $\begin{array}{r}0.247 \\
(8.3) \\
\text { (6) }\end{array}$ \\
\hline 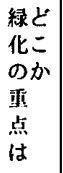 & $\mid$\begin{tabular}{l|}
11 \\
$A 2$ \\
$A 3$ \\
$A 4$ \\
15 \\
$A 6$
\end{tabular} & $\begin{array}{c}-0.517 \\
\cdots \ldots . \\
0.142 \\
-0.553 \\
-0.151 \\
0.899\end{array}$ & $\begin{array}{r}1.452 \\
(21.0) \\
\text { (1) }\end{array}$ & $\begin{array}{c}0.050 \\
\ldots \ldots . \\
0.003 \\
\ldots \ldots . \\
0.107 \\
-0.126\end{array}$ & $\begin{array}{c}0.233 \\
(8.4) \\
(5)\end{array}$ & $\mid \begin{array}{c}-0.018 \\
-0.033 \\
-0.069 \\
0.221 \\
0.085 \\
0.008\end{array}$ & $\begin{array}{r}0.291 \\
(9.5) \\
\text { (6) }\end{array}$ & $\begin{array}{r}-0.149 \\
0.070 \\
0.245 \\
-0.012 \\
-0.114 \\
0.031\end{array}$ & $\begin{array}{r}0.393 \\
(13.3) \\
\text { (3) }\end{array}$ \\
\hline $\begin{array}{l}\text { 緑题 } \\
\text { 化点 } \\
\text { 严 } \\
\text { 開 }\end{array}$ & \begin{tabular}{l|}
$A 1$ \\
$A 2$ \\
$A 3$ \\
$A 4$
\end{tabular} & $\begin{array}{r}0.131 \\
-0.230 \\
-0.232 \\
0.672\end{array}$ & $\begin{array}{r}0.903 \\
(13.1) \\
(4)\end{array}$ & $\begin{array}{r}-0.126 \\
0.023 \\
0.085\end{array}$ & $\begin{array}{c}0.210 \\
(7.5) \\
\text { (6) }\end{array}$ & $\mid \begin{array}{r}-0.149 \\
-0.012 \\
0.047 \\
0.193\end{array}$ & $\begin{array}{r}0.342 \\
(11.2) \\
\text { (5) }\end{array}$ & $\begin{array}{r}-0.039 \\
0.037 \\
0.222 \\
-0.090\end{array}$ & $\begin{array}{r}0.312 \\
(10.5) \\
\text { (4) }\end{array}$ \\
\hline $\begin{array}{l}\text { 施の } \\
\text { 設必 } \\
\text { 緑要 } \\
\text { 化性 }\end{array}$ & $\mid$\begin{tabular}{l|}
$A 1$ \\
$A 2$ \\
$A 3$
\end{tabular} & $\begin{array}{c}-0.020 \\
0.163 \\
\cdots \cdots\end{array}$ & $\mid \begin{array}{c}0.183 \\
(2.7) \\
\text { (9) }\end{array}$ & $\begin{array}{c}0.031 \\
-0.147 \\
\cdots \cdots\end{array}$ & $\begin{array}{c}0.179 \\
(6.4) \\
\text { (7) }\end{array}$ & $\begin{array}{r}0.001 \\
0.020 \\
-0.024\end{array} \mid$ & \begin{tabular}{|c}
0.045 \\
$(1.5)$ \\
(1l)
\end{tabular} & $\begin{array}{r}-0.005 \\
0.038 \\
-0.190\end{array}$ & $\begin{array}{c}0.229 \\
(7.7) \\
\text { (8) }\end{array}$ \\
\hline $\begin{array}{l}\text { 施化 } \\
\text { 没の } \\
\text { 内意 } \\
\text { 緑䔐 }\end{array}$ & $\begin{array}{l}A 1 \\
A 2 \\
A 3 \\
A 4\end{array}$ & $\begin{array}{c}0.007 \\
\ldots \ldots . \\
-0.059 \\
0.061\end{array}$ & $\begin{array}{r}0.121 \\
(1.7) \\
\text { (10) }\end{array}$ & $\begin{array}{r}-0.062 \\
0.089 \\
-0.019 \\
0.454\end{array}$ & $\begin{array}{r}0.515 \\
(18.5) \\
\text { (2) }\end{array}$ & $\begin{array}{r}0.013 \\
-0.130 \\
-0.046 \\
0.127\end{array}$ & $\begin{array}{c}0.257 \\
(8.4) \\
(7)\end{array}$ & $\begin{array}{r}-0.022 \\
0.125 \\
0.012 \\
-0.030\end{array}$ & $\begin{array}{c}0.154 \\
(5.2) \\
\text { (10) }\end{array}$ \\
\hline $\begin{array}{l}\text { 緑の } \\
\text { の限 } \\
\text { 面度 } \\
\text { 畨 }\end{array}$ & \begin{tabular}{|l|}
$A 1$ \\
$A 2$ \\
$A 3$ \\
$A 4$
\end{tabular} & $\begin{array}{r}0.137 \\
-0.286 \\
-0.093 \\
-0.039\end{array}$ & \begin{tabular}{|c}
0.423 \\
$(6.1)$ \\
(7)
\end{tabular} & $\begin{array}{c}0.041 \\
\ldots \ldots . \\
-0.036 \\
-0.038\end{array}$ & $\begin{array}{c}0.079 \\
(2.8) \\
\text { (1) }\end{array}$ & $\begin{array}{c}0.060 \\
\ldots \ldots \\
0.273 \\
-0.193\end{array}$ & $\begin{array}{r}0.466 \\
(15.2) \\
\text { (2) }\end{array}$ & $\begin{array}{r}-0.059 \\
-0.155 \\
-0.028 \\
0.074\end{array}$ & $\begin{array}{r}0.228 \\
(7.7) \\
\text { (9) }\end{array}$ \\
\hline $\begin{array}{l}\text { 接緑 } \\
\text { 近化 } \\
\text { 部協 } \\
\text { 你力 } \\
\text { の }\end{array}$ & $\begin{array}{l}A 1 \\
A 2 \\
A 3 \\
A 4 \\
A 5\end{array}$ & $\begin{array}{r}-0.745 \\
0.100 \\
-0.090 \\
-0.129 \\
0.416\end{array}$ & $\begin{array}{r}1.161 \\
(16.8) \\
\text { (2) }\end{array}$ & $\begin{array}{r}-0.035 \\
0.073 \\
-0.183 \\
0.268 \\
-0.069\end{array}$ & $\begin{array}{r}0.451 \\
(16.2) \\
\text { (3) }\end{array}$ & $\begin{array}{r}-0.164 \\
-0.035 \\
0.294 \\
-0.067 \\
0.080\end{array}$ & $\begin{array}{r}0.459 \\
(15.0) \\
\text { (3) }\end{array}$ & $\begin{array}{r}0.071 \\
0.054 \\
-0.162 \\
0.027 \\
-0.031\end{array}$ & $\begin{array}{l}0.233 \\
(7.9) \\
\text { (7) }\end{array}$ \\
\hline $\begin{array}{l}\text { 接の } \\
\text { 道闻 } \\
\text { 緑题 } \\
\text { 化点 }\end{array}$ & \begin{tabular}{l|}
11 \\
$\Lambda 2$ \\
$\Lambda 3$ \\
14
\end{tabular} & $\begin{array}{r}0.080 \\
-0.071 \\
-0.149 \\
-0.006\end{array}$ & $\begin{array}{c}0.229 \\
(3.3) \\
\text { (8) }\end{array}$ & \begin{tabular}{|r}
-0.404 \\
-0.163 \\
-0.090 \\
0.128
\end{tabular} & $\begin{array}{r}0.532 \\
(19.1) \\
\text { (1) }\end{array}$ & $\mid \begin{array}{c}-0.245 \\
\ldots \ldots \\
-0.202 \\
0.112\end{array}$ & $\begin{array}{r}0.357 \\
(11.7) \\
\text { (4) }\end{array}$ & $\begin{array}{r}-0.095 \\
0.042 \\
-0.052 \\
0.199\end{array}$ & \begin{tabular}{|c}
0.293 \\
$(9.9)$ \\
(5)
\end{tabular} \\
\hline $\begin{array}{l}\text { 都の } \\
\text { 市確 } \\
\text { 保 } \\
\text { 緑 } \\
\text { 地 }\end{array}$ & $\begin{array}{l}\mathrm{A} 1 \\
\mathrm{~A} 2 \\
\mathrm{~A} 3 \\
\mathrm{~A} 4 \\
\mathrm{~A} 5\end{array}$ & $\begin{array}{c}-0.092 \\
-0.388 \\
-0.188 \\
0.375 \\
\cdots \ldots .\end{array}$ & $\begin{array}{r}0.763 \\
(11.1) \\
\text { (5) }\end{array}$ & $\begin{array}{r}0.048 \\
0.048 \\
-0.117 \\
-0.036\end{array}$ & $\begin{array}{c}0.165 \\
(5.9) \\
(8)\end{array}$ & $\begin{array}{r}0.059 \\
0.065 \\
0.057 \\
-0.143 \\
0.015\end{array}$ & $\begin{array}{c}0.208 \\
(6.8) \\
(8)\end{array}$ & $\begin{array}{r}-0.004 \\
-0.001 \\
0.088 \\
0.049 \\
-0.337\end{array}$ & $\begin{array}{r}0.425 \\
(14.3) \\
\text { (2) }\end{array}$ \\
\hline $\begin{array}{l}\text { 地法 } \\
\text { 域 } \\
\text { 化 } \\
\text { 垈 } \\
\text { 方 }\end{array}$ & $\begin{array}{l}\mathrm{A} 1 \\
\mathrm{~A} 2 \\
\mathrm{~A} 3 \\
\mathrm{~A} 4 \\
\mathrm{~A} \\
\mathrm{~A} \\
\mathrm{~A}\end{array}$ & $\mid \begin{array}{c}0.135 \\
\ldots \ldots \\
0.061 \\
0.088 \\
-0.244 \\
-0.938\end{array}$ & $\begin{array}{r}1.073 \\
(15.5) \\
\text { (3) }\end{array}$ & $\begin{array}{c}0.005 \\
\ldots \ldots \\
-0.201 \\
0.113 \\
0.011 \\
\ldots \ldots . .\end{array}$ & $\begin{array}{r}0.314 \\
(11.3) \\
\text { (4) }\end{array}$ & $\mid \begin{array}{r}-0.144 \\
-0.199 \\
0.019 \\
0.248 \\
0.365 \\
-0.147\end{array}$ & $\begin{array}{r}0.564 \\
(18.5) \\
\text { (1) }\end{array}$ & $\begin{array}{r}0.002 \\
0.166 \\
-0.103 \\
-0.241 \\
0.206 \\
0.019\end{array}$ & $\begin{array}{r}0.447 \\
(15.1) \\
\text { (1) }\end{array}$ \\
\hline & 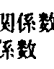 & & $\begin{array}{l}0.8647 \\
0.7478\end{array}$ & & $\begin{array}{l}0.6315 \\
0.3988\end{array}$ & & $\begin{array}{l}0.6260 \\
0.3919\end{array}$ & & $\begin{array}{l}0.5340 \\
0.2852\end{array}$ \\
\hline
\end{tabular}

敷地全般の緑化必要性の認識と、直接的に利用する職員 の楽しみを中心に緑化を考えていることが分った。

(2)接道緑化に対する管理者の意識

次に、接道緑被長さの割合との関係を捉える分析では、 表一7に示すように、社寺・戸建住宅及びスーパー・工場 の、接道緑被長さの割合の高い施設の管理者が、要因の 第 1 位を「地域緑化の方法」（寄与率各 $18.5 \% 、 15.1 \%$ ) としており、カテゴリーでは「住民と管理体制を作る」 となっている。要因の第 2 位には、社寺・戸建住宅は、 「緑の貢献の限度」となり、カテコリリーの「市民の意見 を考虑する」にしている。スーパー・工場では「都市の 緑地の確保」で、カテゴリーは「一定規模以上の土地」
となっている。つまり、接道緑被長さの割合の高い社寺 ・戸建住宅、スーパー・工場の管理者は、地域緑化の方 法として住民と管理体制を作ることを望んでいることが 明らかにされた。更に、社寺・戸建住宅の管理者は、緑 の貢献のあり方として、市民の意見を考虑すると答え、 スーパー・工場の管理者は、都市の緑地の確保には一定 規模以上の土地を対象に考えると答えている。

また、幼稚園・学校の管理者は、要因の第 1 位は「緑 化の重点はどこか」（奇与率21.0\%）であり、カテゴリ 一では「その他」となっている。要因の第 2 位には「接 道部分の緑化協力」となり、カテコリーでは負のスコア で「新・改築時に緑地新設」としている。即ち、接道緑 被長さの割合の高いこれらの施設では、新・改築時の緑 地新設を望んでいないことが示された。

次に、病院・文化体育では、要因の第 1 位は「接道緑 化の問題点」（寄与率 $19.1 \%$ ）となり、カテゴリーでは 「通路部分にあたるから」が負のスコアで最も寄与して いる。つまり、接道緑被長さの割合の高い病院・文化体 育の管理者は、「接道緑化の問題点」として、接道部分が 通路・進入口部分にあたることが少ないと答えている。

(3)まとめ

以上の分析から、緑被面皘の割合の高い社寺・戸建住 宅やスーパー・圷場の管理者は、高木の植栽を緑化の重 点にしていると答え、緑化意識の高いことが窥われる。 また、幼稚園・学校の管理者は、緑化の問題点として維 持管理の費用をあげている。病院・文化体亩の管理者は、 緑化の意義として、部内者の目を楽しませることが重要 であるとして、緑の位置つけが施設側と都市側で異なる 場合のあることを示した。

次に、接道緑被長さの割合の高い施設の管理者のうち、 社寺・戸建住宅やスーパー・工場では、地域緑化に住民 との管理体制を受け入れると考えていることが分った。 また、幼稚園・学校では、新・改築時の緑地新設を㕵ん でいないことが分った。更に、病院・文化体育では接道 部分が通路・進入口部分にあたることは少ないと答えて いる。

\section{5 まとめと今後の課題}

本研究で明らかにした大規模施設の緑被面積及び接道 緑被長さに関する主な事柄は、下記のごとく示される。 (1)施設用途ごとの平均で、緑被率は社寺が最大となり、 最小はスーパーである。接道緑被長さ率は、公園・運動 場が最大となり、スーパーが最小になっている。緑被率 及び接道緑被長さ率は、施設用途によって異なるが、一 般に公共系の施設で高く、戸建住宅を除く民間系施設て 低くなっており、地域緑化に大きな位置を占める公共系 緑地の保全が重要である。また、施設用途ごとに緑化推 
進・保全の計画が必要と思われる。

(2)大規模施設の緑被面積、接道緑被長さは、それぞれ 非建ぺい地面積、接道空地長さとの関係でみると、スー パーを除いてかなり高い正の相関を示す。つまり、緑被 面積は非建ぺい地面積の変化に応じて、又、接道緑被長 さは接道空地長さの変化に応じて、一定の割合で增減し ている。

(3)施設内の非特定用途地に占める緑被部分の割合は、図 -6に示す緑化可能直線式によって上限値を求め、緑被部 分の計測值を求めることによって、緑化可能面積を推定 することが出来た。また、接道緑化可能長さは、非特定用 途長さの内の空地部分の長さを測定することで求めた。 これらの推定結果から、敷地緑化の可能性は、戸建住宅、 病院、幼・保育園、学校等で高いことが明らかとなった。 (4)施設管理者の意識と緑化の度合いとの関係は、公共系 施設と民間系施設で差異がみられる。高木を緑化の重点 と考えている施設で緑被面積の割合が高く、この事は緑 化推進に重要な示唆を与えるものである。また、大規模 緑地を抱える学校などで、維持管理の費用が問題と答え ていることなど、緑化行政にとっての課題を示した。

本論文は、市街地における各種大規模施設の施設内土 地利用を調查し、現況の土地利用に基づいて緑化可能面 積を求めた。この緑化可能面積は、今後の增築用として 留保されている空地についてのヒアリング調查を行って おらず、現時点で特定用途地としての利用予定がない限 り、樹木植栽が可能な部分として扱っている。

一方、景観的な視点から見た場合、非建ぺい地の特定 用途で利用されていても、中心市街地にあっては緑化施 策の必要性が認識されている。例えば、現況で広い面積 の鍳車場や資材置場等に、人工的に利用されているが景 観上緑化が必要と考えられる部分等については、何らか の基準に基づいた、例えば「緑化必要部分」とも呼ばれ る概念の導入により、緑化をすすめる必要がある。

事実、今回の調查においても、駐車場や工場や流通施 設などで、敷地面樍の $20 \%$ 近くに及ぶ接道部分や隣接す る住宅との境界部分の植栽を行い、景観向上と周辺への 配虑につとめている例が少なからず認められた。

これらのことから、今後大規模施設の緑化を推進する ために、緑化必要部分を規定する要件を明らかにするこ とが必要となる。

しかし、この緑化必要部分を規定する壆準の設定には、 景観的視点から求められるもののほか、各施設の立地条 件や施設内の土地利用に関する諸条件等から要求される 多くの個別的要件の分析が必要で、その解明にはさらに 広籍な調查解析が必要之考えられる。

以上のように、本研究では、大規模施設に求められる 緑化必要部尔についての考察が残されており、今後の課
題として継続的に研究したいと考えている。

末尾ながら、調查にご協力頂いた施設管理者の方々に 心からお礼を申しあげる次第である。

注

注1）屒崎市：長崎市都市緑化推進部画報告费、1989. 東京都港区：港区緑と水の総合計面推進方策、1990. 広島市：広島市総合緑化計画、1986。

注2）仙台市：仙台市都节緑化推進計画、1987. 東京都文京区：文京区緑化基本郡画、1991.

注3）市街化区域内のすへての用途地域にわたる、21小学枚区を対象として、敫地

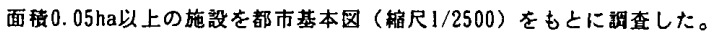
施設数合㖕1573。校区単位の集部結果は次表の通りである。

表-8 大規模施設の校区別集計（予備調查）

\begin{tabular}{|c|c|c|c|c|c|c|c|}
\hline & $\begin{array}{l}\text { 地区人 } \\
\text { 口 } \\
(\Lambda)\end{array}$ & $\begin{array}{l}\text { 交区面 } \\
\text { 篎 } \\
\text { (ha/区) }\end{array}$ & $\begin{array}{l}\text { 挴設数 } \\
\text { (所/区) }\end{array}$ & $\begin{array}{l}\text { 施設面 } \\
\text { 挠 } \\
\text { (ha/区) }\end{array}$ & $\begin{array}{l}\text { 篦設面 } \\
\text { (\%) }\end{array}$ & 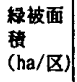 & $\begin{array}{r}\text { 縃被染 } \\
\text { (\%) }\end{array}$ \\
\hline 合 㖕 & 199488 & 3033 & 1573 & 642.6 & 21.2 & 90.0 & 3.0 \\
\hline & 9499 & 144 & 75 & 30.6 & 21.2 & 4. 3 & 3.0 \\
\hline 最大 & 17616 & 215 & 111 & 51.3 & 43.1 & 14.0 & 6.5 \\
\hline & 2289 & 32 & 23 & 6.0 & 12.9 & 0.6 & 1.9 \\
\hline
\end{tabular}

注4）建設省：都市緑化技術開然调査報告書、1979.

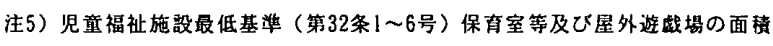

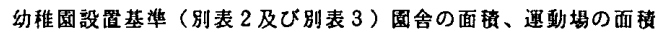

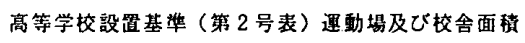

注6）宇都宮市：宇都宮市都市緑化推進楌画・基本部画、1987. 文京区：文京区緑化基本計画、1991. 富山市：富山市級化推谁計画報告春、1989.

注7)フォトマップ: 能本日日新闑社、1987.

参考文献

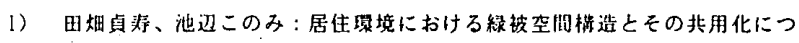
いて、造略雓誌、46-5、pp229-234、1983.

2）丸田頼一、小野敏正：住宅地とその接道部の緑化の施策に関する基磁的研 究、造四唋誌、46-5、pp206-210、1983.

3）田代順孝：住宅地の緑化に関す万副西論的研究(1)、日本造圆学会昭和54年

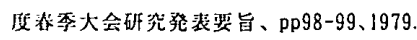

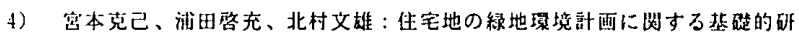

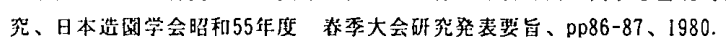

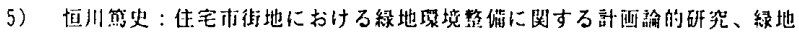

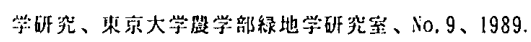

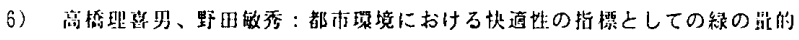

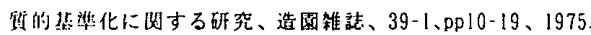

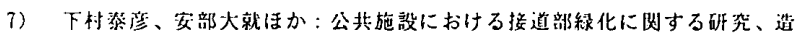
约制誌、53-5、pp353-358、1990.

(1993 年 1 月 25 日原稿受理, 1994 年 3 月 16 日採用決定) 